\title{
耳下腺腫瘍と顔面神経の位置関係の判定法
}

一ママイオモニターを利用した 1 万法一

鄭 漢 忠・金井義明・園 部昌治・佐々木和也

加納 尚・柴田敏之・福田 博

\section{A trial to disclose the relations between parotid gland tumors and facial nerves \\ a method making use of a myomonitor}

\author{
Kanchū Tei • Yoshiaki Kanai • Masaharu Sonobe \\ Kazuya SASAKI - Hisashi Kanoh - Toshiyuki Shibata \\ Hiroshi Fukuda
}

\begin{abstract}
In the surgical management of parotid gland tumors, it is very important to know the relationships beteen tumors and facial nerves preoperatively. However, it is not always easy to understand the relations precisely.

In this study, the relationships in 10 patients with benign parotid tumors were evaluated by a myomonitor. The result was that the relationships evaluated by the myomonitor were precicely same as the surgical findings in all cases.

This method is simple and useful to predict the relationships between benign parotid tumors and facial nerves preoperatively.
\end{abstract}

Key words: parotid tumor, facial nerve, myomonitor

緒

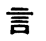

耳下腺腫瘍の訩断に際して, 腫瘍の進展籟囲, 腫瘍の 良性, 悪性の判別と同時に, 腫湯と顔面神経の位置関係 を明らかにすることは，手術上さまざまな利点がある。 顔面神経の保存を特に要求される良性腫瘍では, その意 義は大きい.今回われわれは, 腫痬と顔面神経の位置関係 を明らかにするため，耳下腺良性腫瘍10症例について， 術前にマイオモニターを用いた検査を行い，その手術所 見とを比較検討し，良好な結果を得たので報告する．

\section{観 察 対 象}

対象は昭和 57 年 10 月から昭和 60 年 7 月までの 2 年 9 か

北海道大学学部口腔外科学第 1 講座

（主任：福田博教授）

The First Department of Oral Surgery, School of Dentistry, Hokkaidō University (Chief: Prof. Hiroshi Fukuda)

受付日：昭和60年11月14日
表 1 対象の性別および年龄分布

\begin{tabular}{|c|c|}
\hline 年 龄 & 人 数 \\
\hline 20 代 & 1 \\
\hline 30 代 & 5 \\
\hline 40 代 & 2 \\
\hline 50 代 & 0 \\
\hline 60 代 & 2 \\
\hline 計 & 10 \\
\hline 男 性 & 4 \\
\hline 女 性 & 6 \\
\hline
\end{tabular}

月の間に, 北海道大学歯学部附属病院第 1 口腔外科を受 診し，臨床所見，唾液腺造影法，超音波断層法， CT, RI などの検查所見より，耳下腺良性腫場と診断され， 手術を行い，術前にマイオモニター検査を行った10症例 である. 表 1 に対象症例の性別掞よび年龄分布を，表 2

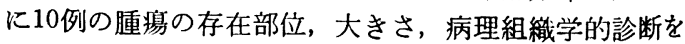
示した。 またコントロールとして，25３0歳の健康成人 男子20名に対し同様の測定を行った。 
表 2 対象10例の尰演の位置, 大きさおよび病理組 織学的診断

\begin{tabular}{|c|c|c|c|}
\hline $\begin{array}{l}\text { 症例 } \\
\text { No. }\end{array}$ & 尰㴾の位置 & $\begin{array}{c}\text { 腫瘍径 } \\
(\mathrm{mm})\end{array}$ & $\begin{array}{l}\text { 病理組緎学的 } \\
\text { 診 }\end{array}$ \\
\hline 1 & 左下靧後部 & $40 \times 50$ & 多形性腺腫 \\
\hline 2 & 左下顎後部 & $30 \times 25$ & 多形性腺腫 \\
\hline 3 & 左耳介下部 & $40 \times 40$ & 多形珄腺腫 \\
\hline 4 & 右耳介下部 & $35 \times 35$ & 多形性腺腫 \\
\hline 5 & 左耳下腺咬筋部 & $20 \times 20$ & 多形性腺腫 \\
\hline 6 & 左耳下腺咬筋部 & $20 \times 15$ & 多形珄腺腫 \\
\hline 7 & 左耳介下部 & 拇指頭大 & 腺リンパ腫 \\
\hline 8 & 左下顎後部 & $35 \times 40$ & 多形性腺腫 \\
\hline 9 & 右耳介下部 & 拇指頭大 & 多形珄腺尰 \\
\hline 10 & 左耳下腺咬筋部 & $65 \times 55$ & 多形性腺腫 \\
\hline
\end{tabular}

\section{検 査 方 法}

今回われわれが測定に用いたのは，米国マイオトロー クス社製の J 2 型および J 3 型マイオモ二ターである (写真 1)．J 3 型は每分40回の短形波パルスを発生する 経皮的電気神経刺激装置で，パルス持続時間は約 500 $\mu \mathrm{sec}$ ，電圧 $7.8 \sim 10 \mathrm{~V}$ ，電流は 0 25 mA まで連続的に 可変である。写真 2 K示すよ5にマイオモニターの筋電 極を，被験者の患側は尰瘍直上に，健側は患側と左右対 称的な位置に貼付し，バランスつまみを left あるいは Rightにセットし，片側ずつ電気神経刺激を行った，被 験者の表情筋の動きが出現するまで刺激強度を徐々に上 け゚，表情筇の動きが出現した時のマイオモニターの刺激 強度目盛りを一側の測定値とした，測定は一側 3 回ずつ 行った後, マイオモニターのケーブルを左右交換して再 度 3 回ずっ，一側䛠計 6 回行った。判定は左右側別 に平均值を求め，左右の平均值の差をるって行った。 コ ントロール群についても注济同様に行った，対象症例群 においては, 約 2 年 9 か月にわたって各患者の手術前に 測定したが，コントロール群の測定はほぼ同一時期に, 同一の器種を用いて行った.

\section{結果}

表了《示すように，コントロール群では測定㯰は全例 目盛り 1 以下で，左右差はほとんど認めなかった。 また 同一被験者に括いて下顎後部，耳介下部，耳下腺咬筋部 の 3 箇所に筋電極の位置を変兄測定した場合でも，左右 の測定値特よび測定値の左右差に変化はなかった、ま た，これらコントロール群の測定値の電流レベルでは, 下䫇運動は自覚的にも他覚的にも認められず，頻回の測 定による測定值の大幅な变動も認めなかった，表 4 は対

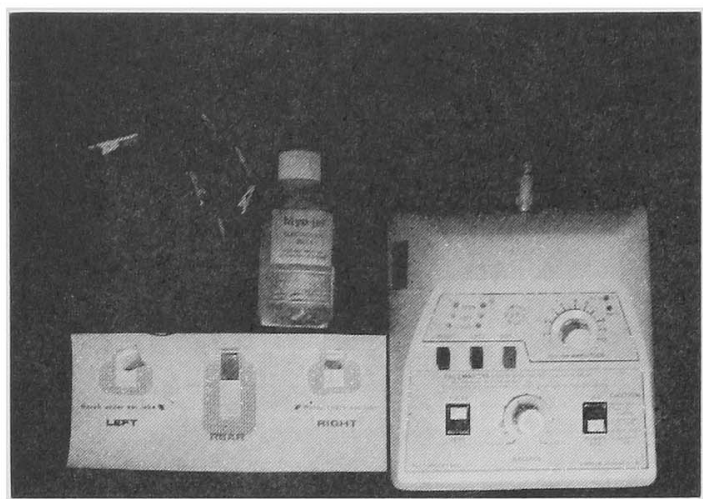

写真 $1 \mathrm{~J} 3$ 型、イオモニター

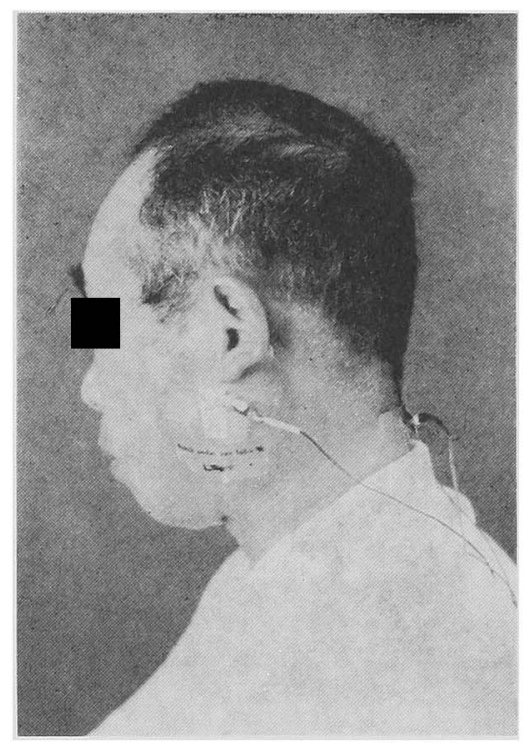

写真 2 マイオモニターの筋電極を 患者の董痬直上に貼付した 状態

表 3 コントロール群*の測定値

\begin{tabular}{c|l|l||l|l|l}
\hline No. & 右 & 左 & No. & 右 & 左 \\
\hline 1 & 0.9 & 0.8 & 11 & 0.5 & 0.5 \\
2 & 0.8 & 0.8 & 12 & 0.6 & 0.5 \\
3 & 0.8 & 0.8 & 13 & 0.8 & 0.8 \\
4 & 0.7 & 0.6 & 14 & 0.7 & 0.7 \\
5 & 0.8 & 0.7 & 15 & 0.7 & 0.7 \\
6 & 0.9 & 1.0 & 16 & 0.9 & 1.0 \\
7 & 0.6 & 0.7 & 17 & 0.7 & 0.7 \\
8 & 0.5 & 0.5 & 18 & 0.8 & 0.7 \\
9 & 0.7 & 0.6 & 19 & 0.9 & 0.9 \\
10 & 0.7 & 0.6 & 20 & 0.5 & 0.5 \\
\hline
\end{tabular}

* 25 30翇の健康成人男子 20 名 
表 4 対象10例のマイオモニター検査の測定値および術前の予測と手術所見との比較

\begin{tabular}{|c|c|c|c|c|c|}
\hline \multirow{3}{*}{$\begin{array}{c}\text { 症 例 } \\
\text { No. } \\
1\end{array}$} & \multicolumn{3}{|c|}{ マイオモニターの測定值 } & \multicolumn{2}{|c|}{ 腫癔と顔皅神経の位置関係 } \\
\hline & 健 側 & 患 & & マイオモニターによる予測 & 手術所見 \\
\hline & 2.5 & 1. 8 & $\downarrow$ & * 浅 層 & 浅 尿 \\
\hline 2 & 3. 6 & 5.0 & $\uparrow$ & 深 尿 & 深 層 \\
\hline 3 & 3.5 & 5.5 & $\uparrow$ & 深 淭 & 深 層 \\
\hline 4 & 3.0 & 1.6 & $\downarrow$ & 浅 尿 & 浅 層 \\
\hline 5 & 3.2 & 2.8 & $\downarrow$ & 浅 䝠 & 浅 層 \\
\hline 6 & 2.1 & 1. 0 & $\downarrow$ & 浅 周 & 浅 尿 \\
\hline 7 & 0.9 & 1. 2 & $\uparrow$ & 深 翼 & 深 層 \\
\hline 8 & 4.0 & 3.2 & $\downarrow$ & 浅 盗 & 浅 㞛 \\
\hline 9 & 1. 4 & 1.6 & $\uparrow$ & 深 層 & 深 層 \\
\hline 10 & 0.6 & 1. 7 & $\uparrow$ & 樑 層 & 深 層 \\
\hline
\end{tabular}

*浅層とは，顔而神経が腫瑄の浅層に位置することを示す。

象症例10例について, マイオモニタ一検査の左右の測定 值および左右差に基つくく，腫瘍と顔面神経の位置関係の 予測と手術所見とを比較した結果である。表で明らかな よらにマイオモニター検査による予測と手術所見は全例 一致した。

考察

マイオモニターは一般に歯科において，靧関節症など の際の筋緊張緩和に汎用されているが，その原理が経皮 的な電気神経刺激であることを利用し ${ }^{1,2)}$ ，われわれは 耳下腺良性腫瘍之顔面神経の位置関係を明らかにするた めの応用を試みた。すなわち図 1 に示すよらに，顔面神 経が腫瘍より深層にある場合には，腫湟の存在により筋 電極下組織抵抗は增大し，患側の測定値は健側より大と なり，逆に図２に示すよらに，顔面神経が腫瘍より浅層 にある場合には, 患側の測定値は健側より小となると考 えた。この仮説に基づき，対象10症例に対しマイオモ二 ター検査を施行し，きわめて良好な結果を得ることがで きた。コントロール群では太り気味の人では，やせ型の 人に比べやや大きな值をとる傾向は認めたが，全例 1 以 下の測定值であり，測定值としては比較的バラッキの少 ない，安定した值が得られた。対象症例群ではコント口 一ル群に比べて測定值の大きな例を認めるが，これは症 例群においては都合により使用したマイオモニターが， 単一のものではなかったためと思われる。したがって各 数值に関しては，絶対値といらょりはあくまでも左右差 に意味があるものと思われる。

現在, 耳下腺腫浧と顔面神経の位置関係はおもに CT で検討されている。CT を用いた両者の位置関係の予测 については，高い確率で予测できたといら報告もむる

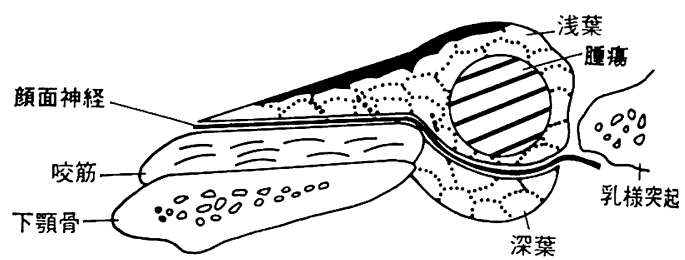

顔面神経が腫瑒の深層に存在する場合 患側の測定值 $>$ 健側の測定值

図 1 腫瘍と顔面神経の位置関係（I）

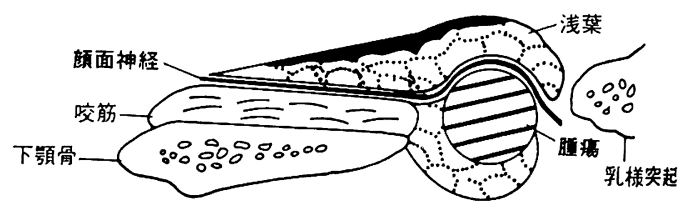

顔面神経が腫湟の浅層に存在する場合 患側の測定值<健側の測定值

図 2 腫湯と顔而神経の位置関係（II）

が3,4)， あくまで推測に止まるという意見が一般的であ

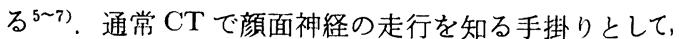
各スライスにより乳様突起, 茥状突起, 頡二腹筋, 下顎㣪 静脈などがあげられている．Sone ら ${ }^{8)}$ は腫瘍が耳下腺 上方部に存在する時は乳様突起と茎乳突起が，腫瘍が耳 下腺下方部に存在する時には下顎後静脈が河者の位置関 係を示唆すると述べており，山下9) は下䫇骨上行枝を基 準にして, 腫瘍が浅葉或いは深葉に存在するかの判定を 行い，高い確率で予測できたと述べている，一方 Conn $ら^{10}$ は 5 屁休の検索から, 顔面神経は下顎骨の最後端か ら $8.5 \mathrm{~mm}$ の孤を描くと結諭している。そこで，われわ 
表 5 山下の方法, Conn らの方法, マイオモ二タ 一检查と手術所見の比洨

\begin{tabular}{|c|c|c|c|c|c|c|c|c|}
\hline No. & \multicolumn{2}{|c|}{$\begin{array}{l}\text { 山下の } \\
\text { 方法 }\end{array}$} & \multicolumn{2}{|c|}{$\begin{array}{l}\text { Conn } 5 \\
\text { の方法 }\end{array}$} & \multicolumn{2}{|c|}{$\begin{array}{l}\text { マイオモ= } \\
\text { ター検査 }\end{array}$} & \multicolumn{2}{|c|}{ 手術所見 } \\
\hline 1 & 浅 & 葉 & 湺 & 葉 & 深 & 葉 & 深 & 葉 \\
\hline 2 & 浅 & 葉 & 浅 & 葉 & 浅 & 葉 & 浅 & 葉 \\
\hline 3 & 浅 & 䒚 & 浅 & 葉 & 浅 & 葉 & 浅 & 葉 \\
\hline 4 & 浅 & 藮 & 浅 & 葉 & 深 & 葉 & 深 & 葉 \\
\hline 5 & 浅 & 葉 & 媣 & 藮 & 媣 & 葉 & 哚 & 葉 \\
\hline 6 & 浅 & 集 & 樑 & 集 & 深 & 葉 & 深 & 葉 \\
\hline 7 & & 藮 & 浅 & 藮 & 浅 & 葉 & 浅 & 葉 \\
\hline 8 & 浅 & 葉 & 浅 & 藮 & 深 & 葉 & 哚 & 葉 \\
\hline 9 & & $f$ & ク & & 浅 & 葉 & 浅 & 集 \\
\hline 10 & & 藮 & 浅 & 葉 & 浅 & 葉 & 浅 & 葉 \\
\hline
\end{tabular}

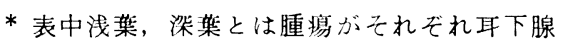
浅葉あるいは樑葉に存在することを示す。

れは今回の10例中，アーチファクトのため検討の困難な 1 例を除いた 9 例につき，上述した山下の方法および Conn らの方法とマイオモニター検査法による予測との 比較検討を試みた。比較対象として，山下および Conn らの方法を用いたのは，雨者の方法が CT 上の各スライ 不間の差を比較的無視できると考えたからである。結果 は表 5 に示すよらに, 山下の方法では 9 例中 4 例, Conn らの方法では 9 例中 7 例, マイオモニタ一検査法では全 例が手術所見と一致した。このような比較を行うには当 然 CT の使用器種の違いによる解像力の差 ${ }^{11,12)}$, 検者の 読影力等の諸因子を考虑しなければいけないが，山下の 方法では CT 上で腫瘍の境界がかなり明瞭であっても， その判定に苦虑する例が多く, Conn らの方法では下靧 骨上行枝より後方へ大きく進展した腫沮を浅葉のものと 誤まることが多かった。一方，マイオモ二ター検查法で は,このように判定に難沾した例はなく、全例に明らかな 左右差を認めた。 しかし本法に関しても, 今後の課題と して 2，3の問題に対する検討が必要と思われた．第 1 に腫瘍の組織学的性状の問題である。今回の対象症例で は10例中， 1 例の腺リンハ腫を除きすべて多形性腺腫で あり,この組織型の腫湟に関しては，われわれの考え方が 正しかったことが証明されている。しかし他の組織型, すなわち神経性，血管性，リンパ性などの腫瘍に関して は，現時点では不明である，第 2 に腫瘍の大きさの問題 である．今回の測定に打いても症例 $5 ， 7 ， 9$ のごとく 腫瘍径の小さなもの（拇指頭大）では, 測定値の左右差 が小さい傾向を認めたが，はたしてどの程度の大きさま での腫瘍で左右差を認めることができるのか.この点に 関しても現時点では不明といわざるを得ないが，一方で は小さな腫瘳の場合，顔面神経との位置関係が手術上あ まり問題とならないのも事実である。逆に腫瘳が大き
く, 局所的に顔面神経を強く王迫し, 神経が neurapraxia の状態に陥いった結果, 本法の測定値に影響を与える可 能性も否定はできない，第 3 に筋電極の問題である，笳 電極は両側皮覤に確実に密着させて貼付するのが原則で あり，その貼付状態の違いにより電導性に差が生じると いわれている. われわれも本原則を尊重し, 左右の筋電 極の貼付状態に差のないように心がけているが, 腫陽の 形態, 位置により, 患側と健側の貼付状態が左右全く同 様と断言できない場合もある。しかしそのような貼付状 態の差により，どの程度本法の測定値が左右されるかは 明らかではない．また現在までのところ，左右の貼付状 態の差により測定值に影響を与えたと考えられるケース は経験していない，最後に悪性腫瘍の問題であるが，悪 性腫瘍はその浸潤的性質から，程度の差こそあれ，直接 神経に影響を及ぼす可能性を秘めており ${ }^{13,14)}$ ，また手術 アプローチ的にも良性腫陽と異なるため, 本法のもつ意 義は少ないのではないかと考えている。しかし近年悪性 度の低い悪性腫瘍に関しては, 顔面神経保存の方向が唱 われており，この点に関しても，今後本法の応用につい、 て症例を重ね検討する予定である。

\section{結論}

今回われわれはマイオモニターを利用し，耳下腺良性 腫陽と顔面神経との位置関係を明らかにする方法を考察 したので報告した。

1.コントロール群では测定值の左右差はほとんど認 めなかった。

2. 症例群では全例に测定値の明らかな左右差を認め, マイオモニター検査による耳下腺腫晹と顔面神経との位 膡関係の予測と手術所見が全例一致した。

3. CT で耳下腺腫瘍と顔面神経の位置関係を把握す るのは容易ではなく，本法の有用性が確認された。

本論文の要旨は, 第30回日本口腔外科学会総会(東京) に扎いて発表した。

\section{引用 文 献}

1)山下敦：マイオも二ターの正しい使い方(I) クインテッセンス 5: 182-188 1978.

2) Bernard, J., Samuel, S., et al.: Neural conduction of the myomonitor stimulus: A quantative analysis. J Prosthet Dent september: 245-253 1975.

3) Nick, B.R., Robert, H.M., et al.: Computed tomography of the major salivary glands. AJR 139: 547-554 september 1982.

4) Eyjolfsson, O., Nordshus, T., et al.: Sialography and CT-Sialography in the diagnosis 
of parotid masses. Acta Radiology Diagnosis 25: Fasc 51984.

5）小池吉郎, 鈴木八郎: 耳下腺腫瘍の訩断, 治療 についての 2，3 の問題点. 耳番 24: 917-929 1978.

6) Peter, M.S. and Hugh, F.B.: The combined CT-Sialogram. Radiology: 387-390 May 1980.

7）松山文彦, 谷口郷美, 他: 耳下腺部扣よび周辺 腫瘤のCT 診断。耳奥 75(增 2)：677-685 1982.

8) Shusuke, S. and Hiromitsu, T.: CT of parotid tumors. AJNR 3: March-April 143-147 1982.

9) 河本和友, 松永 亨編: CT 像と耳鼻咽喉科. 第 1 版, 篠原出版, 東京, 1984, 109-128頁.

10) Conn, I.G. and Wiesenfeld, D.: The anatomy of the facial nerve in relation to CT-sialography of the parotid gland. The British Journal of Radiology 56: 901-905 1983.

11) Stephan, G.: Computed tomography in the diagnosis of parotid gland tumors. The British Journal of Radiology 55: 182-188 1982.

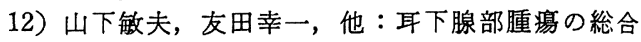
診断——RI, CT, USG——.耳番 71(7)：9519651978.

13) Takayuki, K. and Takeshi, K.: Malignant parotid tumors and facial nerve paralysis. Arch Otorhinolaryngol 240: 139-144 1984.

14) John, E.W.: The facial nerve in parotid malignancy. The American Journal of Surgery Vol 146: 493-496 October. 